\title{
The Role of 'Think-Pair-Share' in Enhancing the Moroccan University Students' Speaking Skills in Online Classes
}

\author{
Mounia Benjelloun \\ National School of Applied Sciences, Hassan I University, Settat, Morocco \\ E-mail: mounibenjelloun@gmail.com
}

Cite this article as: Benjelloun, M. (2021). The Role of 'Think-Pair-Share' in Enhancing the Moroccan University Students' Speaking Skills in Online Classes. International Journal of Second and Foreign Language Education, 1(1), 17-27. https://doi.org/10.33422/ijsfle.v1i1.60

\begin{abstract}
Speaking English as a foreign language presents one of the most common challenges for learners of English due to many factors related to their perception of the teacher as "a sage on the stage," their own shyness, a lack of appropriate vocabulary and accurate grammar, and a lack of cooperative learning skills. To help students remedy this problem, the Think-Pair-Share' strategy was used in this study of online classes during the COVID 19 pandemic. Research has demonstrated that learners can improve their speaking skills and learn more effectively through meaningful collaboration and sharing. This study aims to investigate the role of the Think-Pair-Share' approach in promoting students' speaking skills. The study adopts a qualitative approach and addresses the following two research questions: (i) To what extent does the Think-Pair- Share help in improving students' speaking skills? (ii) How can this improvement be justified? Twenty-eight first-year Moroccan university students took part in this study. The research instruments used combined pre- and post-speaking tests, students' self-evaluation, and classroom observations. Data were video recorded, analysed qualitatively using the FCE speakingassessment criteria, and compared to the students' self- evaluation of their own performance. The results show that the Think-Pair-Share strategy enabled predominantly average and weak students to exchange their views on a range of familiar topics with more ease, confidence, and fluency using more appropriate vocabulary and a clearer organisation of ideas. Although the learners still had problems with their pronunciation and accurate grammar, they demonstrated better interactive communication.
\end{abstract}

Keywords: challenges, cooperative learning, online classes, communication, confidence, fluency, accuracy

\section{Introduction}

Speaking English fluently and accurately is the most challenging productive skill for almost all learners of English given that, unlike writing, it requires learners to speak spontaneously to express meanings to other people in a limited time and without reflecting on what has already been said.

The ability to speak fluently not only presupposes a knowledge of language features but also the ability to process information and language on the spot (Harmer, 1992:269). As a result, students may end up making mistakes, feeling embarrassed, and being reluctant to take part in speaking activities. What makes it even worse is that due to the COVID-19 pandemic restrictions, developing learners' speaking skills in online classes has become more challenging than face-to-face classes, especially because it is a new learning experience for most Moroccan students, particularly in the public sector. The primary challenge is that most students have internet connection issues they are unwilling to fix for

(C) The Author(s). 2021 Open Access. This article is distributed under the terms of the Creative Commons Attribution 4.0 International License, which permits unrestricted use, distribution, and redistribution in any medium, provided that the original author(s) and source are credited. 
two main reasons: they cannot afford it because most students belong to low-income families and do not have any other sources of income, as they are challenged with busy schedules and do not have time to work part-time.

Teachers find it equally challenging to teach speaking skills in online classes as they need to integrate several criteria, such as appropriate vocabulary, accurate grammar, and correct pronunciation, which are more difficult to appropriate in an online environment. Nevertheless, many studies have dealt with teaching and learning techniques and strategies to boost speaking skills.

The 'Think-Pair-Share' is one of the learning strategies that has proved to be effective in improving students' speaking skills. This study is, therefore, an attempt to gain some preliminary insights into the role of 'Think-Pair-Share' in enhancing learners' speaking skills in online classes.

\section{Theoretical Framework: 'Think-Pair-Share'}

The assumptions that underlie our focus on the role of 'the think-pair-share' in the development of students' speaking skills in online classes are inspired by the theoretical framework of Lyman's 1981: "Think-Pair-Share."

The Think-Pair-Share (TPS) is a cooperative learning strategy and, as the name suggests, involves three functional actions in a sequential order: individual, intra-group, and inter-group (Chen \& Chiu, 2016). First, it allows students time to think individually about a concept, a problem, or an answer to a question. Second, it provides them with an opportunity to share their ideas in pairs before sharing their newly constructed ideas with the rest of the class.

The 'Think-Pair-Share' can be used in online classes in two different rooms: the main room and breakout rooms. The first step can be done in the main room, where all the students take a few minutes to think about an answer to a question assigned by the teacher, who in the second step splits them into virtual breakout rooms found in the Course link's Virtual Classroom tool or the licenced Zoom learning platform. Students can, then, work in pairs collaboratively to check answers. The teacher can move from one room to another to make sure students know what they are supposed to do, and that they are doing the task in English and not switching to their mother tongue. When the time allocated for the task is over, the teacher can close all the rooms and students are allowed 60 seconds to return to the main room, where they can exchange ideas and discuss further details.

Both the teacher and the students play an active role in the 'Think-Pair-Share' cooperative learning strategy.

To make oral communication efficient and effective throughout the process, the teacher should make students more aware of speaking sub-kills, including grammatical structures, correct pronunciation, vocabulary, and useful interactive phrases and expressions appropriate to for the assigned task.

"In some ways, speaking can be considered the most difficult skill to acquire because it requires command of speech production sub-skills like vocabulary retrieval, choice of grammatical patterns, and sociocultural competence" (Celce-Murcia and Olshtain, 2000:102).

Several studies have been conducted on the vital role these sub-skills can play in enhancing students' speaking skills, especially in cooperative learning environments.

Grammatical competence has been proved to be an integral part of communicative competence. Students will not develop grammatical competence if this aspect is not focused on from the start of the students'course (Canale \& Swain , 1980). 
Grammar knowledge is, indeed, essential for competent users of a language. (Harmer, 1991). In other words, language users should be familiar with grammatical rules that can help them orginise their ideas and express them in a meaningful way.

Teaching grammar in context is one of the most effective methods of helping learners of English improve their speaking skills. According to Thornbury (1999), if learners are given a chance to work out grammar rules by themselves, then they are more likely to remember the rules and use them in spoken interactions to convey more meaningful messages.

In terms of vocabulary, according to (Edge, 1993), having enough vocabulary in L2 can lead to an effective interaction among students and eventually successful discussion and communication. Contariwise, lack of vocabulary knowledge impeds real communication of EFL learners to a great extent.( Adam, 2016)

Developing strategies for learning vocabulary has been the main concern of many educators for decades, as there is still uncertainty about how teachers can help learners acquire and use new vocabulary in meaningful discussions (Schmitt, 2008).

One useful strategy that teachers can use is to focus on active vocabulary words that learners need to complete an assigned task. Doff (1988) and Nation (2005) suggested using the target words in examples and asking questions so the students can notice how the words are used. They also suggest exploring several aspects of word knowledge and inviting the learners to actively process the words.

Drilling the target words, with a special focus on pronunciation, is another effective strategy that can lead to meaningful interactions. Harmer (2011) observed that pronunciation is not only about the mastery of different sounds, but mainly the ability to use them appropriately within a specific discourse and in different contexts. Similarly, Nation (2005) argued that retrieving (rather than simply seeing the item again) is more effective because it more closely resembles the performance required during normal use (Nation, 2005, p. 79)

Indeed, good pronunciation can make a positive first impression on the rest of the class, boosts the confidence and intelligibility of the speaker, and improves overall classroom communication.

Instructors also need to familiarize students with the functional language suitable for different assigned tasks such as the language for giving opinions, preferences, agreeing and disagreeing, etc.

Providing learners with all these useful language tools, namely appropriate vocabulary, accurate grammar, useful functional language, and proper pronunciation can result in a more relaxed, less stressful, and less threatening learning environment, where students of mixed abilities learn and use language to exchange ideas and interact with their peers with more fluency and confidence.

Students should also be made aware of the importance of using these sub-skills that can help them succeed not only in their short- and long-term studies, but also in their future careers, where an advanced level of English is one of the key entry requirements to the job market, both in Morocco and abroad.

Before applying the 'Think-Pair-Share' steps in real or virtual classroom contexts, teachers should check learners' understanding of what they are supposed to do in each task or activity through asking them ICQS (Instruction checking questions) to avoid any kind of misunderstanding or confusion over the assigned task and to avoid any feelings of embarrassment in front of their peers.

On the other hand, learners also play an active role in this cooperative learning process. Jacob (2006) mentioned five important roles that learners must perform: As a facilitator, he coordinates the group's works; As a recorder, he should record what the group has achieved; As a reporter, he reports back the group's work to the other groups; As a timekeeper, he reminds the group of how much time left to 
complete the assigned task(s); And, as an observer of collaborative skill, he makes sure the students are using collaborative skills that are important to the group's interaction.

Indeed, using the Think-Pair-Share approach has several personal, inter-personal and intra-personal benefits. The key to enhancing students' speaking skills initially depends on allowing everyone time to construct his or her own knowledge individually. As a result, students can organise their ideas in a better and clearer way, reduce the sense of inhibition and embarrassment with their partners, and feel more engaged, willing, and confident to speak in English. In fact, as Dörnyei (1997) and other educators have observed, students are more willing to speak and act in a foreign language in small groups and feel more confident to produce utterances in their L2. (Dörnyei, 1997; Jacobs \& McCafferty, 2006). Moreover, students learn the wisdom of listening to each other's views, develop more interactive communication skills. Eventually, if the process is used frequently in their online courses, they acquire more knowledge and gain more confidence to share their ideas with the rest of the class, especially after having discussed them with partners. In short, cooperative learning can be characterized as a social process in which knowledge is acquired through the successful interaction between the group members (Cohen, 1994).

\section{Review of literature}

Several studies have dealt with the role of Think-Pair-Share in improving learners' speaking and cooperative skills. Lyman (1981), Edge (1993), and Parker (2009) found out that the Think-Pair-Share increased interaction, cooperation and communication among students. Pimm (1987) and Pressely (1992) agreed that the Think-Pair-Share helped learners elaborate ideas discussed with pairs. Brady \& Tsay (2010) discovered that the strategy improved students' achievements in speaking. Other studies have addressed the role of speaking sub-skills, such as vocabulary, grammar, and pronunciation in improving students' speaking skills, while working collaboratively in online classes. A study by Quintero (2018) on the impact of online collaborative groups to teach and learn English pronunciation in a public university in Colombia determined that constant practice and consistent feedback on pronunciation mistakes eventually contributed to the improvement of pronunciation.

Studies on the role of vocabulary knowledge in speaking development have shown that a lack

of vocabulary knowledge resulted in poor speaking performances by learners of English in Saudi EFL institutions. Hamad (2013) and Khan et al. (2018). Consequently, instructors were encouraged to integrate vocabulary-learning-strategy instruction into the curriculum taught in Saudi EFL institutions.

In general, incorporating TPS into one's teaching practices can be helpful in both effective teaching and active learning. Raba \& Harzallah (2015) In another study by Rabat (2017), this cooperative learning strategy played a positive role in improving students' oral communicative skills, creating a cooperative learning environment, and enhancing students' motivation to learn.

One note of caution: in another study conducted by Mannurung (2017), the implementation of TPS with university students was not substantial enough in cycle I (middle of term) to result in noticeable improvement in the student's speaking skills. As a result, TPS was implemented in cycle II (end of term), which then brought significant improvement to the students' speaking achievement. Mannurung's study demonstrates that the application of TPS needs sufficient time to be assessed, at least one full 12week semester.

Though ample research and theory document the role of TPS in enhancing speaking skills, very limited studies have dealt with the influence of TPS on improving speaking skills in online classes. Therefore, this study can provide added value to this area of research. 


\section{Research Methodology}

The study is an applied-research project which adopts a qualitative research approach. The study focuses on the development of the speaking skills of Moroccan university students using a Think-PairShare strategy of cooperative learning in the 2020-2021 academic year.

Twenty-eight first year Moroccan university students of logistics and transport at the National School of Applied Sciences (ENSA) constitute the target population for the present study.

To assess students' prior and post speaking competence, the study used three main research instruments: A pre- and a post-experimental oral test, a pre- and a post-student self-evaluation, and classroom observations. According to Johnson \& Johnson (1999:2) assessment can be used to diagnose students' present level of knowledge and skills, monitor students' progress toward learning goals to help form the instructional program, and to provide data to judge the final level of students' learning.

A pre- and a post-experiment oral test were used at the beginning and at the end of the first semester. Most of the students were tested in pairs, except for two groups of three students. The contents of both tests included questions about the same topics related to the units covered during the semester (e.g., education and learning, companies, and marketing). The choice of these topics was based on the fact that learners needed to improve their knowledge of topics related to their field of studies. Students were tested on the criteria highlighted in the FCE (First Certificate of English) B2 speaking assessment, namely grammar and vocabulary, discourse management, pronunciation, and interactive communication.

Students can demonstrate better use of vocabulary and grammar when they interact with other students. Moreover, Taylor and Wigglesworth, (2009) argued that testing students' speaking ability in pairs (or in groups) may enable them to demonstrate their interactional competence or interactive communication skills more broadly than in the traditional one-to one oral proficiency interview format. The tests were recorded and analysed in terms of the criteria mentioned above. As shown in table 1, the FCE Assessment Scales are divided into six bands from 0 to 5, with 0 being the lowest and 5 the highest. Descriptors for each criterion are provided for bands 1, 3 and 5 and indicate what a candidate is expected to demonstrate at each band at Level B2 of the Common European Framework of Reference (CEFR), and the descriptors for band 3 and above generally indicate performance of at least B2 level. The choice of this tool was based on the students' levels at the beginning of the term, which ranged from starter to intermediate, except for a couple of students who demonstrated a more advanced and more independent level than their peers. The purpose of using this tool was to find out whether students could become more competent, more successful communicators and be understood in most situations.

The second research instrument included a pre- and a post-test student self-evaluation. In the words of McMillan \& Hearn (2008) 'Self-assessment occurs when students judge their own work to improve performance as they identify discrepancies between current and desired performance'. To put it differently, pre-evaluation can raise students' awareness of their weaknesses and make them set goals to improve themselves. Post-evaluation gives students an opportunity to evaluate what they have learned, to track their progress and improve their performance toward meeting goals they have set for themselves in learning English.

To help students assess their performance in a simple and effective way, a simplified version of the FCE speaking assessment criteria was provided. To assess progress in the students' speaking skills and to deal with any issues that may arise in subsequent classes, the researcher conducted classroom observations of the students' performance during the 'Think-Pair-Share' activity at three different times (the beginning, middle, and end) of the term. 
Table 1.

Speaking assessment scores

\section{FCE (B2 level)}

Analytical Scales

\begin{tabular}{|c|c|c|c|c|c|c|c|c|c|c|}
\hline & 0 & 1.0 & 1.5 & 2.0 & 2.5 & 3.0 & 3.5 & 4.0 & 4.5 & 5.0 \\
\hline $\begin{array}{l}\text { Grammar and } \\
\text { Vocabulary } \\
\text { Control } \\
\text { Range } \\
\text { Appropriacy }\end{array}$ & \multirow{4}{*}{ 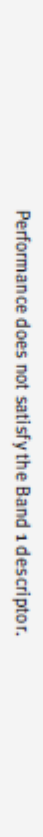 } & $\begin{array}{l}\text { - Shows a good degree of control } \\
\text { of simple grammatical forms. } \\
\text { - Uses a range of approp riate } \\
\text { vocabularywhen talking about } \\
\text { everyday situations. }\end{array}$ & \multirow{4}{*}{ 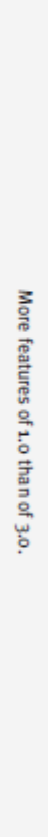 } & \multirow{4}{*}{ 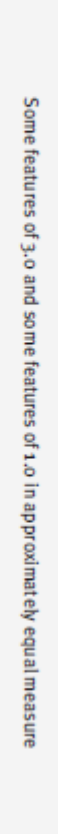 } & \multirow{4}{*}{ 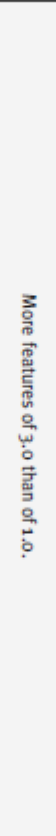 } & $\begin{array}{l}\text { - Shows a good degree of control } \\
\text { of simple grammatical forms, } \\
\text { and attempts some complex } \\
\text { grammatical forms. } \\
\text { - Uses a range of appropriate } \\
\text { vocabulary to give and } \\
\text { exchange views on a range of } \\
\text { familiar topics. }\end{array}$ & \multirow{4}{*}{ 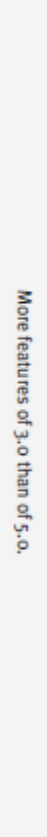 } & \multirow{4}{*}{ 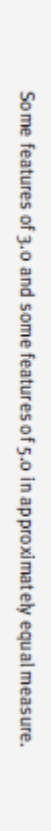 } & \multirow{4}{*}{ 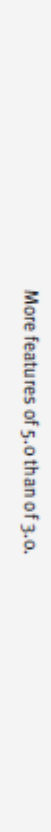 } & $\begin{array}{l}\text { - Shows a good degree of control } \\
\text { of a range of simple and some } \\
\text { complex grammatical forms. } \\
\text { - Uses a range of ap propriate } \\
\text { vocabulary to give and } \\
\text { exchange views on a wide range } \\
\text { of familiar topics. }\end{array}$ \\
\hline $\begin{array}{l}\text { Discourse } \\
\text { Management } \\
\text { Extent } \\
\text { Relevance } \\
\text { Coherence } \\
\text { Cohesion }\end{array}$ & & $\begin{array}{l}\text { - Produces responses which are } \\
\text { extended beyond short } \\
\text { phrases, despite hesitation. } \\
\text { - Contributions are mostly } \\
\text { relevant, despite some } \\
\text { repetition. } \\
\text { - Uses basic cohesive devices. }\end{array}$ & & & & $\begin{array}{l}\text { - Produces extended stretches } \\
\text { of language despite some } \\
\text { hesitation. } \\
\text { - Contributions are relevant and } \\
\text { there is very little repetition. } \\
\text { - Uses a range of cohesive devices. }\end{array}$ & & & & $\begin{array}{l}\text { - Produces exten ded stretches } \\
\text { of language with very little } \\
\text { hesitation. } \\
\text { - Contributions are releva nt a nd } \\
\text { there is a clear organisa tion } \\
\text { of ideas. } \\
\text { - Uses a range of cohesive } \\
\text { devices and discourse markers. }\end{array}$ \\
\hline $\begin{array}{l}\text { Pron unciation } \\
\text { intonation } \\
\text { Stress } \\
\text { individual sounds }\end{array}$ & & $\begin{array}{l}\text { - Is mostly intelligible, and has } \\
\text { some control of phonological } \\
\text { features at both utterance and } \\
\text { word levels. }\end{array}$ & & & & $\begin{array}{l}\text { - Is intelligible. } \\
\text { - Intonation is genera lly } \\
\text { appropriate } \\
\text { - Sentence and word stre ss } \\
\text { is generally accurately placed. } \\
\text { - Individual sounds are generally } \\
\text { articulated clearly. }\end{array}$ & & & & $\begin{array}{l}\text { - Is intelligible. } \\
\text { - Intonation is approp riate. } \\
\text { - Sentence and word stress } \\
\text { is accurately placed. } \\
\text { - Individual sounds are } \\
\text { articulated clearly. }\end{array}$ \\
\hline $\begin{array}{l}\text { Interactive } \\
\text { Communication } \\
\text { in itiating } \\
\text { Responding } \\
\text { Development }\end{array}$ & & $\begin{array}{l}\text { - Initia tes and responds } \\
\text { appropriately. } \\
\text { - Keeps the interaction going with } \\
\text { very little prompting and supp ort. }\end{array}$ & & & & $\begin{array}{l}\text { - Initiates and responds } \\
\text { appropriately. } \\
\text { - Maintains and develops the } \\
\text { interaction and negotiates } \\
\text { towards an outcome with very } \\
\text { little support. }\end{array}$ & & & & $\begin{array}{l}\text { - Initiates and responds } \\
\text { app rop riat ely. linking } \\
\text { contributions to those } \\
\text { of other speakers. } \\
\text { - Ma intains and develops the } \\
\text { interaction and negotiates } \\
\text { towards an outcome. }\end{array}$ \\
\hline
\end{tabular}

\section{Findings}

\section{Pre-test \& post- test}

In this section, the results of the pre and post tests are reported. As revealed in the tables below, there was some progress in two of the speaking criteria, namely vocabulary and discourse management. Students improved their scores from 2-3 to 4-5 in vocabulary and discourse management. The implication behind this achievement may be linked to students' awareness of their weaknesses in the first test as well as their exposure to varied vocabulary during the lessons and willingness to practice the pronunciation of relevant words with partners during TPS activity that helped them to enrich their vocabulary repertoire. Moreover, they started to produce more extended stretches of language with very little hesitation.

Producing grammar inaccurately and continuously was another common issue in students' performance.

And although they still had problems with their pronunciation and accurate grammar, they demonstrated better interactive communication. In other words, they managed to maintain and develop the interaction, and negotiate towards an outcome, with very little support.

Table 2.

Pre-test scores

\begin{tabular}{|l|c|c|c|}
\hline \multicolumn{1}{|c|}{ Pre-test scores } & $\begin{array}{c}\mathbf{0 - 1} \\
\text { Number of students }\end{array}$ & $\begin{array}{c}\mathbf{2 - 3} \\
\text { Number of students }\end{array}$ & $\begin{array}{c}\mathbf{4 - 5} \\
\text { Number of students }\end{array}$ \\
\hline Gra\&voc & 4 & 18 & 6 \\
\hline DM & 10 & 12 & 6 \\
\hline Pron & 12 & 11 & 5 \\
\hline IC & 16 & 9 & 3 \\
\hline
\end{tabular}


Table 3.

Post-test grades

\begin{tabular}{|l|c|c|c|}
\hline \multicolumn{1}{|c|}{ Post-test scores } & $\begin{array}{c}\mathbf{0 - 1} \\
\text { Number of students }\end{array}$ & $\begin{array}{c}\mathbf{2 - 3} \\
\text { Number of students }\end{array}$ & $\begin{array}{c}\mathbf{4 - 5} \\
\text { Number of students }\end{array}$ \\
\hline Gra\&voc & 1 & 14 & 13 \\
\hline DM & 3 & 15 & 10 \\
\hline Pron & 6 & 14 & 8 \\
\hline IC & 4 & 10 & 14 \\
\hline
\end{tabular}

\section{Students' self-evaluation of pre-test}

In the students' self-evaluation of the pre-test, students were asked questions on their general impression of their performance in the pre-oral test, areas they needed to work more on, and what they could do to improve their speaking skills.

Twenty-two students out of twenty-eight admitted that their English test was not good due to many reasons related mainly to poor English vocabulary, which led them to feel stressed, anxious, and less confident to answer the questions properly. For instance, one student mentioned: "My answer was simple due to tension and nervousness because of my poor English vocabulary." Another student said: "If I had to evaluate my English test, I will give it 40\% since I think that it wasn't good enough. My problem in English is when I talk to someone the ideas come in Arabic and French and then I have to translate it and that is so tiring."

More than twenty students mentioned that they needed to improve their vocabulary, pronunciation, and grammar to be able to communicate successfully. Six female students believe that they needed to work more on their pronunciation, especially that they feel frustrated when they mispronounce words. They also mentioned that they should master grammar rules that can aid them to communicate well in English.

Seven students are aware of the importance of needing more vocabulary and discourse markers to be able to carry out conversations about different topics related to their field of specialization and eventually to achieve fluency. This may be since the contexts in which English is spoken are limited almost exclusively to the classroom context. However, a lack of reading and exchanging ideas in the classroom could be additional factors that contributed to these results. Nevertheless, while a good number of students note that they needed to attend their English classes regularly, only a couple of students mentioned the importance of learning in pairs to learn from each other. This might be due to a lack of experience in working in pairs and though some students performed well in their first oral test, they were aware that they could have done better if they had been allowed more time to think about the answers. For instance, one student remarked that: "It's somehow hard to get ideas and translate them quickly, so I think my performance wasn't good enough." Nevertheless, she hoped she could speak more fluently by the end of the semester without thinking too much about the answers.

\section{Post- test self-evaluation}

The main questions addressed in the post-course self-evaluation concerned students' feelings about their performance of the post-oral test compared to the pre-oral test, an assessment of the areas they have made progress in, and the factors that contributed to their progress. They were also asked to make suggestions for further improvement in their speaking skills.

First, ten students appreciated being given a chance to evaluate what they have learned and to track their progress toward meeting goals they have set for themselves in learning English. 
Regarding their progress, most students admitted that they had made progress in their speaking skills. They believed that learning new vocabulary words and grammatical structures and being able to use them to interact with their peers have tremendously helped them to speak English and carry out conversations about different topics with more confidence and fluency than before. They also agreed that being given time to think first individually about an answer to a question has helped them organise their ideas, boosted their confidence in expressing their own opinions, and eventually led to more meaningful interaction with other students.

One student observed: "I've had confidence issues. Sometimes my language betrays me, and it just disappears, so giving five or 10 minutes of thinking is good for combining my ideas." Another commented that: "I found this way wonderful because every student presents his opinions, which leads to sharing of ideas that everyone believes in."

Students also felt more comfortable about joining online classes with the help of breakout rooms and started feeling more confident about sharing their ideas with the rest of the class.

They also appreciate being encouraged and challenged to further their skills.

These findings support the benefits of using 'TPS' to help learners organise ideas and feel confident to share them with partners and eventually with the whole class.

Students even suggested additional ways to improve their communication skills, such as working in pairs and teams inside and outside of the classroom to do research on topics related to their field of specialisation, discuss them, and express their own opinions.

This implies that when students can see the benefits of a learning strategy, they feel more responsible for their own learning and motivated to study harder to improve faster.

\section{Classroom observations during think-Pair-Share activity}

Observations of the students' performance during the Think-Pair-Share activity were conducted three times during the term (i.e., the beginning, middle, and end). After the first observation, the instructor provided feedback on the areas that students had problems with and suggested what they needed to do to make progress in their speaking skills.

The first noteworthy finding during the initial observation is that some students were reluctant to join breakout rooms to share their answers with their partners, but explanations vary widely. Students reported that they were not willing to try something they were not familiar with, especially because they already had a bad attitude towards online classes. Even students who participated did not show cooperation and ended up making lots of grammar mistakes, which led to miscommunication among learners. In fact, to be able to speak a language with some degree of proficiency and say what we really want to say, we need to have some grammatical knowledge. In the pre-oral test, one strong student mentioned that it was not motivating to work with some shy or weak students because they switched to Arabic or French, especially when the teacher was not in the breakout room. Regarding vocabulary, most students used only basic vocabulary to exchange information about familiar topics, and misused collocations. In terms of interactive communication, students did not listen carefully to what their partners were saying. As a result, they were not interacting and giving opinions and it was difficult to assess their pronunciation as they did not produce enough language.

After the first observation, the teacher highlighted several new vocabulary words and grammatical structures, drilled them, and stressed the importance of using them for effective interactive communication. 
During the second observation, students started to enjoy working with different partners, encouraging each other to use useful language and learning from each other. Students who were shy and not willing to participate started to share their ideas with more students. Though strong students were still dominating the discussion, some weaker students felt proud when they had used new vocabulary. One student confirmed: "I believe that to become fluent, I must improve my grammar and vocabulary."

During the last observation, students started to demonstrate clearer organization of ideas and an increased willingness to participate in all class activities. They were trying their best to use newly learned language to aid comprehension and communication.

Students who mentioned that they did not have time to develop ideas in the first test performed far better in their second test. They acknowledged the fact that being given time during pair-work activities has tremendously helped them to adequately incoroprate language functions, simple and complex grammatical structures, general and specific vocabulary, pronunciation, leading to fluent and spontaneous communication. Developing into a stronger classroom community was another factor behindthis achievement.

\section{Implications}

Implementing 'Think -Pair-Share' in online classes with Moroccan university students has proved to be an enjoyable and effective cooperative learning strategy in many ways.

Most students, especially average and weak students gained more confidence to speak in front of their peers after having been exposed to the target language and given time to organise their ideas. Consequently, they improved their speaking sub-skills, namely vocabulary and discourse management and demonstrated better interactive communication.

The implication behind this achievement may be linked to students' awareness of their weaknesses in the first test, their exposure to varied vocabulary words and grammatical structures during the lessons and willingness to practice them with partners during TPS activity that helped them to enrich their vocabulary and grammar repertoire. This supports Celce-Murcia and Olshtain's argument that speaking requires command of speech production sub-skills like vocabulary retrieval, choice of grammatical patterns, and sociocultural competence. ((Celce-Murcia and Olshtain, 2000)

Additionally, respecting and listening to each other's views more carefully, widening the discussions and moving them forward were the key to better interaction skills.

Another explanation behind this achievement is that during the last classroom observation, students started to work more collaboratively, assisted each other, to discuss and argue with each other, to assess each other's current knowledge, fill in gaps in each other's understanding, and praise each other's efforts to achieve a common goal.

They acknowledged the fact that being given time during pair-work activities has tremendously helped them to adequately incoroprate language functions, simple and complex grammatical structures, general and specific vocabulary, pronunciation, leading to fluent and spontaneous communication. Developing into a stronger classroom community was another factor behind this achievement though they still had some problems with pronunciation, which may be due to the transfer of their knowledge of the pronunciation of French words to the pronunciation of English words beside not being exposed explicitly to the pronunciation of English words during their formal schooling as mentioned by one of the students might be another contributing factor to this result.

\section{Conclusion}

This research aimed at investigating the role of using 'Think-Pair-Share' cooperative learning strategy in enhancing Moroccan university students' speaking skills in online classes. 
This study has shown that even though TPS was not welcomed by students at the beginning of the term as they raised a wider concern of going back to normal face-to-face classes and were unable to ignore the psychological impact that university closures have had on their physical well-being, it has nevertheless provided them with "food for thought" on given topics and enabled them to formulate individual opinions with their pairs and share the ideas with other students.

Moreover, students were directly involved in the evaluation of their progress, which made them reflect on their learning and set goals to improve their performance with meaningful motivation.

As a result, most students demonstrated improved cooperation because they were given time to overcome their apprehension in communicating and expressing their points of view in a foreign language. More importantly, they spoke with more confidence and fluency, especially after they were provided with new language to guide their interaction more smoothly. Although some students, especially the weak ones, still had problems with grammatical accuracy and pronunciation, they demonstrated better interactive communication overall.

\section{References}

Adam, M. A. A. (2016). Role of Vocabulary Learning Strategies in Promoting EFL Learners Performance. Sudan University of Science and Technology.

Alyassen, W.S. (2014). Cooperative Learning in the EFL Classroom. The 2014 WEI International Academic Conference Proceedings Vienna, Austria. The West East Institute 92

Celce-Murcia, M., \& Olshtain, E. (2000). Discourse and context in language teaching: CA guide for language teachers. (p. 102). Cambridge: Cambridge University Press.

Cohen, A. D. M. (2007). Language learner strategies: Thirty years of research and practice.

Cohen, E. G. (1994) Designing Groupwork. Strategies for the Heterogeneous Classroom (2nd edition). New York: Teachers College Press

Dörnyei, Z. (1997) Psychological processes in cooperative language learning: Group dynamics and motivation, Modern Language Journal, 81, 482-493

Edge,J. (1993). Essentials of English Language Teaching. Longman: New York

Jacobs, G. M. \& McCafferty, S. G. (2006) Connections between cooperative learning and second language learning and teaching, in: S. G. McCafferty, G. M. Jacobs \& A. C. DaSilva Iddings (Eds) Cooperative Learning and Second Language Teaching. Cambridge: Cambridge University Press 18-29

Johnson, D. W., Johnson, R., \& Smith, K. (2006). Active learning: Cooperation in the college classroom. Minnesota: Interaction Book Company.

Harmer, J. (1991). The practice of English language teaching. Longman. Longman: Longman

Khan, R. M.I., Radzuan, N. R. M., Shahbaz,M., Ibrahim, A.H.,\& Ghulam Mustafa (2018). The Role of Vocabulary Knowledge in Speaking Development of Saudi EFL Learners. Arab World English Journal, 9 (1). https://dx.doi.org/10.24093/awej/vo19no1.28

Lyman, F. (1981). The Responsive Classroom discussion. In A.S. Anderson (Ed.), Mainstreaming Digest (pp.109113). College Park, MD: University of Mayland College of Education.

Mc Millan, J.H. \& Hearn, (2008). Student self-assessment: The key to stronger student motivation and higher achievement. University of Kentucky.

Raba, A.A. A (2017). The Influence of Think-Pair Share (TPS) on Improving Students' Oral Communication Skills in EFL Classrooms. Scientific Research. An Academic Publisher.

Raba, A. A. A. M., \& Harzallah, H. T. M. (2015). Effective Teaching from An-Najah National University M.A. Students' Perspectives. Journal of Languages and Culture, 6, 52-60. https://doi.org/10.5897/JLC2015.0325

Slavin, R. E. (1995). Cooperative learning theory, research, and practice. Massachusetts: Simon \& Schuster, Inc.

Taylor, L and Wigglesworth, G (2009) Are two heads better than one? Pair work in L2 assessment contexts, Language Testing 26(3), 325-339.

Thornbury, S. (1999). How to teach grammar. Harlow: Pearson Education Limited 
McMillan, J. H., \& Hearn, J. (2008). Student self-assessment: The key to stronger student motivation and higher achievement. Educational Horizons, 87(1), 40-49.

Manurung, J.E. (2017) Using Think-Pair-Share to Improve Speaking Achievement of the Second Semester English study program of Tidinanti University Palembang. English Community Journal 